\title{
Outdoor air pollution and diminished ovarian reserve among infertile Korean women
}

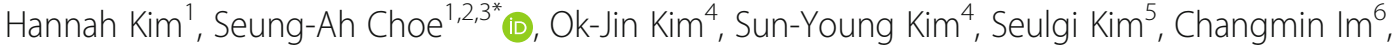
You Shin Kim ${ }^{1}$ and Tae Ki Yoon ${ }^{1}$

\begin{abstract}
Background: Mounting evidence implicates an association between ambient air pollution and impaired reproductive potential of human. Our study aimed to assess the association between air pollution and ovarian reserve in young, infertile women.
\end{abstract}

Methods: Our study included 2276 Korean women who attended a single fertility center in 2016-2018. Women's exposure to air pollution was assessed using concentrations of particulate matter $\left(\mathrm{PM}_{10}\right.$ and $\left.\mathrm{PM}_{2.5}\right)$, nitrogen dioxide $\left(\mathrm{NO}_{2}\right)$, carbon monoxide $(\mathrm{CO})$, sulfur dioxide $\left(\mathrm{SO}_{2}\right)$, and ozone $\left(\mathrm{O}_{3}\right)$ that had been collected at 269 air quality monitoring sites. Exposure estimates were computed for 1, 3, 6, and 12 months prior to the ovarian reserve tests. Anti-Müllerian hormone (AMH) ratio (defined as an observed-to-expected $\mathrm{AMH}$ based on age) and low AMH (defined as $<0.5 \mathrm{ng} / \mathrm{mL}$ ) were employed as indicators of ovarian reserve. We included a clustering effect of 177 districts in generalized estimating equations approach. A secondary analysis was conducted restricting the analyses to Seoul residents to examine the association in highly urbanized setting.

Results: The mean age was $36.6 \pm 4.2$ years and AMH level was $3.3 \pm 3.1 \mathrm{ng} / \mathrm{mL}$ in the study population. Average AMH ratio was $0.8 \pm 0.7$ and low AMH was observed in $10.3 \%$ of women $(n=235)$. The average concentration of six air pollutants was not different between the normal ovarian reserve and low AMH groups for all averaging periods. In multivariable models, an interquartile range (IQR)-increase in 1 month-average $\mathrm{PM}_{10}$ was associated with decrease in $\mathrm{AMH}$ ratio among total population $(\beta=-0.06,95 \%$ confidence interval: $-0.11,0.00)$. When we restrict our analysis to those living in Seoul, IQR-increases in 1 and 12 month-average PM 2.5 were associated with 3\% (95\% $\mathrm{Cl}:-0.07,0.00)$ and $10 \%(95 \% \mathrm{Cl}:-0.18,-0.01)$ decrease in AMH ratio. The ORs per IQR increase in the six air pollutants were close to null in total population and Seoul residents.

Conclusions: In a cohort of infertile Korean women, there was a suggestive evidence of the negative association between ambient PM concentration and ovarian reserve, highlighting the potential adverse impact of air pollution on women's fertility.

Keywords: Air pollution, Ovarian reserve, Anti-Müllerian hormone, Fertility

\footnotetext{
* Correspondence: seungah@korea.ac.kr

'Department of Obstetrics and Gynecology, CHA Fertility Center Seoul

Station, CHA University School of Medicine, Seoul 04637, Korea

${ }^{2}$ Department of Preventive Medicine, Korea University College of Medicine,

Seoul 02841, South Korea

Full list of author information is available at the end of the article
}

(c) The Author(s). 2021 Open Access This article is licensed under a Creative Commons Attribution 4.0 International License, which permits use, sharing, adaptation, distribution and reproduction in any medium or format, as long as you give appropriate credit to the original author(s) and the source, provide a link to the Creative Commons licence, and indicate if changes were made. The images or other third party material in this article are included in the article's Creative Commons licence, unless indicated otherwise in a credit line to the material. If material is not included in the article's Creative Commons licence and your intended use is not permitted by statutory regulation or exceeds the permitted use, you will need to obtain permission directly from the copyright holder. To view a copy of this licence, visit http://creativecommons.org/licenses/by/4.0/. The Creative Commons Public Domain Dedication waiver (http://creativecommons.org/publicdomain/zero/1.0/) applies to the data made available in this article, unless otherwise stated in a credit line to the data. 


\section{Background}

Ovarian reserve is an important indicator of female reproductive potential. It is largely determined by the number and quality of oocytes in the ovaries [1]. Generating oocytes or proceeding to atresia, the number of follicles in the ovaries declines over time because they are not restored [2]. When women are in their late 30s or early 40s, the decrease in follicle pool starts to accelerate and they reach menopause $10-15$ years later $[3,4]$. In $10-26 \%$ of women, ovarian reserve is more diminished than age-related decrease and it can lead to earlier menopause [5-9]. Causes of this diminished ovarian reserve (DOR) remain unknown in most cases [7].

Several epidemiological and clinical studies have suggested that a woman's ovarian reserve is influenced by environmental exposures. For example, heavy smoking, long-term exposure to secondhand smoking, and indoor burning of wood or artificial fire logs have been found to be associated with decreased ovarian reserve in some studies [10,11]; however, these findings were not replicated in other studies [12, 13]. Environmental exposure to endocrine disrupting chemicals such as parabens was reported to be negatively associated with ovarian reserve [14]. Recent reports corroborate that exposure to higher levels of PM is associated low ovarian reserve parameters [15-17]. However, these findings are limited by the small study population. This study assessed the association between air pollution and age-adjusted measures of ovarian reserve in a cohort of women who visited a fertility center in Seoul, Republic of Korea.

\section{Methods}

\section{Study population}

Data of infertile women who visited a single fertility center for fertility evaluation was used. The center is the largest single fertility center of the country located in Seoul, South Korea, and a half of patient population are from outside of the capital area ( 9 provinces of the country). The result of ovarian reserve test and residential address of those who newly visited between January 2016 and September 2018 were obtained. Because our exposure assessment is based on air quality monitoring data, our analysis was restricted to the subjects living within $6 \mathrm{~km}$ from a monitoring station to minimize measurement error [18-20]. Having further excluded women previously diagnosed with chromosomal abnormality, having a history of unilateral or bilateral oophorectomy, and aged $<20$ or $>49$ years, the final study population included 2276 women.

\section{Estimation of ambient air pollution exposure}

Hourly concentrations of particulate matter less than or equal to 10 or $2.5 \mu \mathrm{m}$ in diameter $\left(\mathrm{PM}_{10}\right.$ and $\mathrm{PM}_{2.5}$, respectively), nitrogen dioxide $\left(\mathrm{NO}_{2}\right)$, carbon monoxide
(CO), sulfur dioxide $\left(\mathrm{SO}_{2}\right)$, and ozone $\left(\mathrm{O}_{3}\right)$ measured at the 269 air quality monitoring sites located throughout the country for 2016 and 2018 were used. $\mathrm{PM}_{10}$ and $\mathrm{PM}_{2.5}$ are inhalable particles containing chemical compounds which can reach deep into the lungs and even into the bloodstream [21]. These data were from the $\mathrm{Na}$ tional Institute of Environmental Research (NIER, https://www.nier.go.kr/). The following daily representative concentrations of the six pollutants were determined for each woman: 24-h averages for $\mathrm{PM}_{10}, \mathrm{PM}_{2.5}, \mathrm{NO}_{2}$, and $\mathrm{SO}_{2}$, and maximum of seventeen 8 -h moving averages for $\mathrm{CO}$ and $\mathrm{O}_{3}$. In order to obtain consistent measurements, the daily averages calculated only for days in which $>75 \%$ of hourly measurements $(18 \mathrm{~h})$ were used at each site. The maximum concentrations of $\mathrm{CO}$ and $\mathrm{O}_{3}$ were used because the majority of their production is affected by commuter traffic and sunlight, respectively [22]. Using these daily representative concentrations, average concentrations for the four periods of $1,3,6$, and 12 months before the ovarian reserve test were computed. These four periods of exposure allow us to explore the critical period of exposure, given the immediate and long-term change in ovarian reserve was observed when ovaries are affected by chemical injury $[23,24]$. The exposure estimate of each period at the nearest monitoring sites was assigned to the women based on their geocoded home addresses at the time of the test assuming women's addresses remained the same within a year.

\section{Outcome variable: measurement of ovarian reserve}

Anti-Müllerian hormone (AMH) is a widely used indicator of ovarian reserve in women of reproductive age [25]. Those with serum AMH as low as $0.5-1.1 \mathrm{ng} / \mathrm{mL}$ are likely to respond poorly to ovarian stimulation and thereby show low pregnancy rates in assisted reproductive technology treatments [26]. In addition, DOR manifested as low AMH has predictive values for the risk of cardiovascular disease [27, 28]. The ovarian reserve of each woman was determined by measuring levels of AMH. Serum obtained on menstrual day 2 or 3 was separated from peripheral blood by centrifugation and stored at $-80^{\circ} \mathrm{C}$ until analysis. AMH was measured using the Elecsys ${ }^{\bullet}$ AMH assay (Roche Diagnostics), which is a sandwich assay based on electrochemiluminescence technology. The total duration of the assay is $18 \mathrm{~min}$; the sample volume is $50 \mu \mathrm{L}$. The assay is calibrated against the Beckman Coulter AMH Gen II ELISA assay with a measuring range of $0.01-23 \mathrm{ng} / \mathrm{mL}$. Considering the age-dependent change in $\mathrm{AMH}$, the $\mathrm{AMH}$ ratio, defined as observed AMH divided by age-specific AMH level, was used as an age-adjusted measure of ovarian reserve [29]. The age-specific reference level of AMH was calculated using a previously described 
quadratic model $(\log \mathrm{AMH}=-1.442+0.225 \times$ age $\left.0.004 \times \mathrm{age}^{2}\right)[30,31]$. Given the lower limit of AMH in the minimal criteria for DOR is $0.5 \mathrm{ng} / \mathrm{mL}$ [32], further examination was conducted for the risk of $\mathrm{AMH}<0.5$ ng/mL ("Low AMH") [33, 34].

\section{Covariates}

Information of women's age, bodyweight, height, previous smoking history, working status, and residential address was retrieved from medical records. Bodyweight and height were measured at the time of initial visit. Body mass index (BMI) was calculated by dividing person's weight in kilograms with their height in meters squared and categorized it into one of three groups (low, normal, overweight, and obese) based on the recommended BMI cut-off points for determining overweight and obesity in Asian populations [35]. History of smoking and working status were recorded as binary variables (yes or no).

\section{Statistical analysis}

Descriptive statistics were calculated for the total population over the country. Given women living in capital area may be less deprived socioeconomically and exposed to higher air pollution compared to those living outside, a secondary analysis was conducted restricting to those living in Seoul. The characteristics between Seoul residents and the others were compared. Pairwise correlation structure between air pollutants for different averaging periods was examined with Spearman correlation test. We conducted generalized linear regression analyses for the AMH ratio and logistic regression analyses for low AMH controlling for woman's age. Effect estimates are presented as regression coefficients for $\mathrm{AMH}$ ratio and odds ratios (ORs) for presence of low AMH with their $95 \%$ confidence intervals (95\% CIs) per an interquartile range (IQR) increment in each pollutant concentration. The IQRs were $8.0 \mu \mathrm{g} / \mathrm{m}^{3}$ for $\mathrm{PM}_{10}$, $2.4 \mu \mathrm{g} / \mathrm{m}^{3}$ for $\mathrm{PM}_{2.5}, 8.8 \mathrm{ppb}$ for $\mathrm{NO}_{2}, 1.2 \mathrm{ppb}$ for $\mathrm{SO}_{2}$, $870.0 \mathrm{ppb}$ for $\mathrm{CO}$, and $11.0 \mathrm{ppm}$ for $\mathrm{O}_{3}$. Risk estimates were adjusted for age (excluded in models for AMH ratio which already adjusted for age), BMI, season at the time of testing, previous smoking history, and district of residence in all models. Age in years $(<35,35-40$, or $\geq 40$ years), BMI, working status, history of smoking (yes or no), and season (March to May, June to August, September to November, or December to February) were recorded as categorical variables. The clustering effect of 177 administrative districts was also included in the model using the cluster function of the R package "survival." The AIC and residual deviance of the generalized linear model (which includes all covariates) for AMH ratio were 4498.6 and 865.23. The AIC and residual deviance were 4448.8 and 856.09 when 1-month average
$\mathrm{PM}_{10}$ is added to the model. We fitted generalized additive models with non-parametric smoothing splines to further assess a non-linear exposure-response relationship between air pollutant concentration and $\mathrm{AMH}$ ratio. The model was fitted with gam function of package "gam." We conducted all the analyses in R (R Version 3.2.1).

\section{Results}

The 2276 women who constituted our study population predominantly were working at the time of the ovarian reserve test $(62.9 \%)$, had normal weight $(62.8 \%)$, and reported no history of smoking (97.8\%) (Table 1). The mean age was 36.6 (standard deviation $=4.2$ ) years, and $\mathrm{AMH}$ level was $3.3(3.1) \mathrm{ng} / \mathrm{mL}$ in total population. Average AMH ratio was $0.8(0.7)$ and AMH $<0.5 \mathrm{ng} / \mathrm{mL}$ was observed in $10.3 \%(n=235)$ of total population and $8.6 \%(n=81)$ of Seoul residents showing higher ovarian reserve in Seoul residents than non-Seoul residents. For a given air pollutant, the 1- and 3-month averages were highly correlated (Spearman's correlation coefficient= 0.74-0.87) (Supplementary Figure 1). $\mathrm{PM}_{10}, \mathrm{PM}_{2.5}, \mathrm{NO}_{2}$, and $\mathrm{CO}$ concentrations showed positive correlations, whereas $\mathrm{O}_{3}$ was negatively correlated with all the other pollutants. When comparing between the normal ovarian reserve and low AMH groups, BMI, proportion of smoking, working status, and average concentration of six air pollutants for all averaging periods were not different (Supplementary Table 1). Women in the low $\mathrm{AMH}$ group were older and more likely to live in Seoul.

In multivariable models, an interquartile range (IQR) increase in 1-month average $\mathrm{PM}_{10}$ was associated with a decrease (beta coefficient $=-0.06,95 \%$ confidence interval: $-0.11,0.00$, Table 2) in AMH ratio. Overall associations between air pollutants and $\mathrm{AMH}$ ratio were toward negative, except ozone, although the estimates did not reach statistical significance. The effect size was similar across the different averaging periods in total population.

When restricted to those living in Seoul, the negative association between 1 month-average $\mathrm{PM}_{10}$ and $\mathrm{AMH}$ ratio was consistent. Additionally, IQR increases in 1and 12-month average $\mathrm{PM}_{2.5}$ were associated with $3 \%$ (95\% CI: - 0.07, 0.00) and 10\% (95\% CI: -0.18, -0.01) lower $\mathrm{AMH}$ ratio, respectively. The associations with $\mathrm{NO}_{2}, \mathrm{SO}_{2}, \mathrm{CO}$, and $\mathrm{O}_{3}$ concentrations for four averaging periods were close to null.

For the risk of low AMH, the ORs per IQR increase in the six air pollutants were close to null in total population and Seoul residents (Supplementary table 2). In Seoul residents, a higher 6 month-average $\mathrm{CO}$ was associated with lower odds of low AMH with marginal significance $(0.80,95 \% \mathrm{CI}: 0.64,1.00, P=0.051)$. For the positive associations of 1-month average $\mathrm{PM}_{10}$ (total 
Table 1 Demographic and clinical characteristics and anti-Müllerian hormone (AMH) of the study population, total population ( $n=$ 2,276), Seoul ( $n=1,122)$, and non-Seoul $(n=1,154)$ residents

\begin{tabular}{|c|c|c|c|c|}
\hline & Total population $(n=2276)$ & Seoul residents ( $n=1122)$ & Non-Seoul residents $(n=1154)$ & $P$ for difference ${ }^{b}$ \\
\hline Age (year) & $36.6 \pm 4.2$ & $36.2 \pm 4.1$ & $37.0 \pm 4.3$ & $<0.001$ \\
\hline BMI $\left(\mathrm{kg} / \mathrm{m}^{2}\right)$ & $21.7 \pm 3.1$ & $21.4 \pm 3.0$ & $22.1 \pm 3.3$ & 0.826 \\
\hline$<18.5$ & $243(10.7 \%)$ & $129(11.5 \%)$ & $114(9.9 \%)$ & $<0.001$ \\
\hline $18.5-23$ & $1431(62.8 \%)$ & $746(66.5 \%)$ & $685(59.4 \%)$ & \\
\hline $23-25$ & $300(13.2 \%)$ & $128(11.4 \%)$ & $172(14.9 \%)$ & \\
\hline$\geq 25$ & $302(13.3 \%)$ & $119(10.6 \%)$ & $183(15.8 \%)$ & \\
\hline \multicolumn{5}{|l|}{ Timing of blood test } \\
\hline Mar-May & $750(33.0 \%)$ & $358(31.9 \%)$ & $392(34.0 \%)$ & 0.622 \\
\hline June-Aug & $489(21.5 \%)$ & $252(22.5 \%)$ & $237(20.5 \%)$ & \\
\hline Sept-Nov & $337(14.8 \%)$ & $171(15.2 \%)$ & $166(14.4 \%)$ & \\
\hline Dec-Feb & $700(30.8 \%)$ & $341(30.4 \%)$ & $359(31.1 \%)$ & \\
\hline Smoking history & $51(2.2 \%)$ & $28(2.5 \%)$ & $23(2.0 \%)$ & 0.584 \\
\hline Currently working & $1431(62.9 \%)$ & $783(69.8 \%)$ & $648(56.2 \%)$ & $<0.001$ \\
\hline $\mathrm{AMH}(\mathrm{ng} / \mathrm{mL})$ & $3.3 \pm 3.1$ & $3.5 \pm 3.2$ & $3.1 \pm 3.0$ & 0.001 \\
\hline $\mathrm{AMH}_{\text {ratio }}{ }^{a}$ & $0.8 \pm 0.7$ & $0.8 \pm 0.7$ & $0.8 \pm 0.7$ & 0.055 \\
\hline Low AMH $(<0.5$ ng/mL) & 235 (10.3\%) & $81(8.6 \%)$ & 154 (13.3\%) & 0.025 \\
\hline
\end{tabular}

$B M I$ body mass index, $A M H$ anti-Müllerian hormone

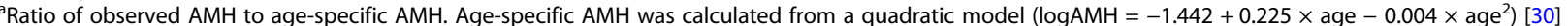

${ }^{\mathrm{b}} P$ values for difference between Seoul residents and non-Seoul residents. Wilcoxon rank sum test and chi-square test were used for comparison

Due to missing information, sum of columns may not equal to the number of total population

population) and $\mathrm{PM}_{2.5}$ with the $\mathrm{AMH}$ ratio (Seoul residents), there was no evidence of important deviations from linearity (Fig. 1).

\section{Discussion}

Our study shows an evidence indicating ambient $\mathrm{PM}_{10}$ concentration within a 1-month period is negatively associated with ovarian reserve in women with infertility; also this negative association was additionally observed for $\mathrm{PM}_{2.5}$ within 1 month and 12 months in Seoul residents. An association with low AMH levels defined as < $0.5 \mathrm{ng} / \mathrm{mL}$ was not evident in our study population. Using a large hospital-based data, we report an association between PM exposure with different averaging periods spanning 1 year and age-adjusted AMH. Although the clinical implication of this short-term impact of air pollution is unclear, this finding may provide additional evidence of potential harm of air pollution among women who are about to undertake fertility treatment.

The negative association between air pollutants and ovarian reserve was present only for PM. It was more evident when the analysis is restricted to Seoul, where the contribution of traffic and secondary aerosol sources is significant in PM generation [36]. Prior studies reported the health effect of air pollution can be greater in the highly polluted cities $[37,38]$ and traffic-related PM may elicit stronger effect than other source-related one [39]. In accordance with these findings, increased distance from the nearest major road was proportionately associated with higher serum levels of AMH [15]. The relatively high traffic-related PM in Seoul may explain the more consistent association with PM compared to total population over the country.

Although the sensitive windows are unclear, it has been suggested environmental exposure within several weeks or months can be critical in AMH-producing follicular pools. A recent study discovered average concentration of $\mathrm{PM}_{2.5}$ within the prior 3 months is associated with decreased antral follicle count [17]. A study of young women exposed to systemic chemotherapy agents showed the reduction of AMH occurs as early as in 15 days following the exposure [23]. Notably, the 12-month average $\mathrm{PM}_{2.5}$ also showed negative association with AMH ratio in Seoul residents. Our divergent finding for 1-month and 12-month PM exposure may reflect different mechanisms involved in the association with ovarian reserve between short- and long-term PM exposures.

The causal relationship that links air pollution to ovarian reserve has yet to be elucidated. Prior reports have suggested that folliculogenesis can be impaired by the increased oxidative stress and cellular apoptosis induced by ambient air containing a range of pollutants [40]. In animal studies, exposure to traffic-related air pollution was found to be correlated with a reduction in the number of antral follicles [41-43]. In studies of the adverse effects of smoking on reproduction, lipid peroxidation 
Table 2 Change in AMH ratio ${ }^{a}$ per interquartile range (IQR)-increase in six air pollutant concentrations among total population ( $n=$ 2276) and Seoul residents ( $n=1122)$

\begin{tabular}{|c|c|c|c|c|}
\hline \multirow{2}{*}{$\begin{array}{l}\text { Air pollutants/ } \\
\text { period }\end{array}$} & \multicolumn{2}{|c|}{ Total population $(n=2276)$} & \multicolumn{2}{|l|}{ Seoul $(n=1122)$} \\
\hline & Coefficient $(95 \% \mathrm{Cl})^{b}$ & $P$ & Coefficient $(95 \% \mathrm{Cl})^{b}$ & $P$ \\
\hline \multicolumn{5}{|l|}{$\mathrm{PM}_{10}$} \\
\hline 1 month-average & $-0.06(-0.11,0.00)$ & 0.035 & $-0.05(-0.08,-0.01)$ & 0.014 \\
\hline 3 month-average & $-0.03(-0.09,0.04)$ & 0.401 & $-0.03(-0.08,0.02)$ & 0.195 \\
\hline 6 month-average & $-0.02(-0.09,0.04)$ & 0.483 & $-0.02(-0.08,0.04)$ & 0.438 \\
\hline 12 month-average & $-0.05(-0.10,0.01)$ & 0.106 & $-0.07(-0.14,0.00)$ & 0.056 \\
\hline \multicolumn{5}{|l|}{$\mathrm{PM}_{2.5}$} \\
\hline 1 month-average & $-0.03(-0.09,0.03)$ & 0.353 & $-0.03(-0.07,0.00)$ & 0.035 \\
\hline 3 month-average & $-0.01(-0.09,0.07)$ & 0.777 & $-0.02(-0.07,0.02)$ & 0.348 \\
\hline 6 month-average & $-0.01(-0.09,0.06)$ & 0.707 & $-0.03(-0.09,0.03)$ & 0.364 \\
\hline 12 month-average & $-0.03(-0.08,0.02)$ & 0.237 & $-0.10(-0.18,-0.01)$ & 0.024 \\
\hline \multicolumn{5}{|l|}{$\mathrm{NO}_{2}$} \\
\hline 1 month-average & $-0.05(-0.12,0.01)$ & 0.093 & $-0.03(-0.08,0.02)$ & 0.234 \\
\hline 3 month-average & $-0.05(-0.11,0.02)$ & 0.143 & $-0.02(-0.07,0.03)$ & 0.348 \\
\hline 6 month-average & $-0.04(-0.10,0.01)$ & 0.142 & $-0.02(-0.07,0.04)$ & 0.532 \\
\hline 12 month-average & $-0.04(-0.09,0.00)$ & 0.061 & $-0.02(-0.07,0.03)$ & 0.387 \\
\hline \multicolumn{5}{|l|}{$\mathrm{SO}_{2}$} \\
\hline 1 month-average & $-0.01(-0.06,0.05)$ & 0.838 & $-0.02(-0.07,0.03)$ & 0.399 \\
\hline 3 month-average & $0.00(-0.05,0.05)$ & 0.999 & $-0.01(-0.06,0.05)$ & 0.805 \\
\hline 6 month-average & $-0.03(-0.08,0.02)$ & 0.258 & $-0.02(-0.09,0.04)$ & 0.525 \\
\hline 12 month-average & $-0.02(-0.08,0.05)$ & 0.621 & $0.00(-0.09,0.08)$ & 0.934 \\
\hline \multicolumn{5}{|l|}{$\mathrm{CO}$} \\
\hline 1 month-average & $-0.03(-0.09,0.03)$ & 0.327 & $-0.03(-0.06,0.00)$ & 0.084 \\
\hline 3 month-average & $-0.02(-0.07,0.04)$ & 0.607 & $-0.02(-0.06,0.02)$ & 0.278 \\
\hline 6 month-average & $-0.03(-0.09,0.03)$ & 0.266 & $-0.02(-0.06,0.03)$ & 0.460 \\
\hline 12 month-average & $-0.03(-0.07,0.01)$ & 0.158 & $-0.03(-0.07,0.02)$ & 0.250 \\
\hline \multicolumn{5}{|l|}{$\mathrm{O}_{3}$} \\
\hline 1 month-average & $0.03(-0.06,0.12)$ & 0.480 & $0.02(-0.02,0.06)$ & 0.250 \\
\hline 3 month-average & $-0.02(-0.10,0.06)$ & 0.638 & $0.00(-0.04,0.05)$ & 0.827 \\
\hline 6 month-average & $0.02(-0.05,0.09)$ & 0.608 & $0.00(-0.05,0.04)$ & 0.886 \\
\hline 12 month-average & $0.02(-0.02,0.07)$ & 0.329 & $0.00(-0.05,0.05)$ & 0.987 \\
\hline
\end{tabular}

$\mathrm{PM}_{10}$ particulate matter, $\mathrm{PM}_{2.5}$ fine particulate matter, $\mathrm{NO}_{2}$ nitrogen dioxide, $\mathrm{CO}$ carbon monoxide, $\mathrm{SO}_{2}$ sulfur dioxide, $\mathrm{O}_{3}$ ozone, $\mathrm{Cl}$ confidence interval

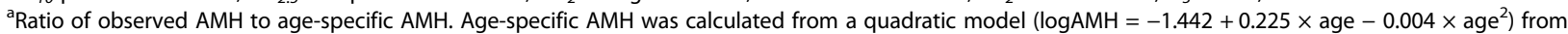
prior study [30]

${ }^{b}$ Adjusted for body mass index (BMI), working status, previous smoking history, season at the time of testing, and district of residence. Estimates in bold have $P$ values $<0.05$

product-which is associated with accelerated follicle loss in women-was found to be higher in passive smokers than in non-smokers [40, 44]. Even though the causative association of air pollution with low AMH is not yet confirmed, there are some clues as to the nature of its deleterious properties. Unlike other air pollutants, for example, ambient PM contains a number of soluble metals and organic components carried on the particle surface, which play an important role in mediating its toxic effects [45]. This pollutant-specific association would need to be replicated in the future studies.

Our study had some limitations, which ought to be taken into consideration for future studies. First, given the study population is young and infertile women, our finding of an association between air pollution and ageadjusted AMH may not be generalizable to general population. Prior studies on air pollution showed the health-impact of air pollution is generally stronger in 


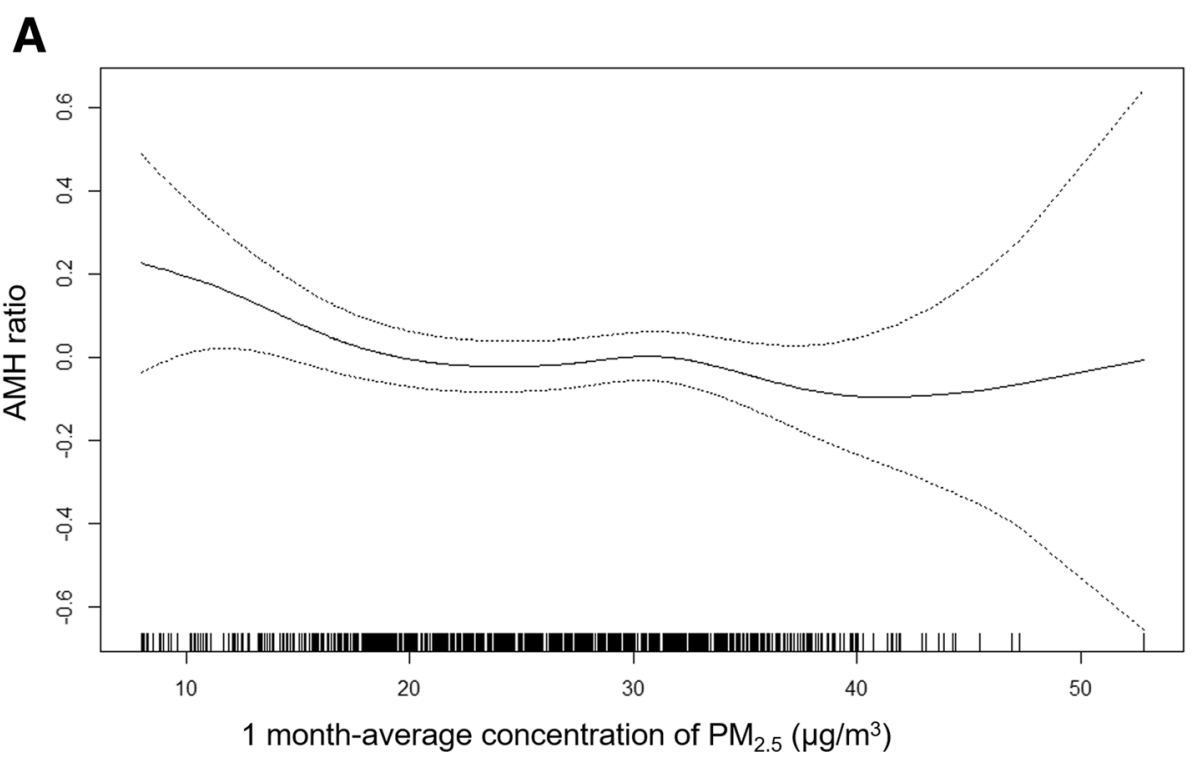

B

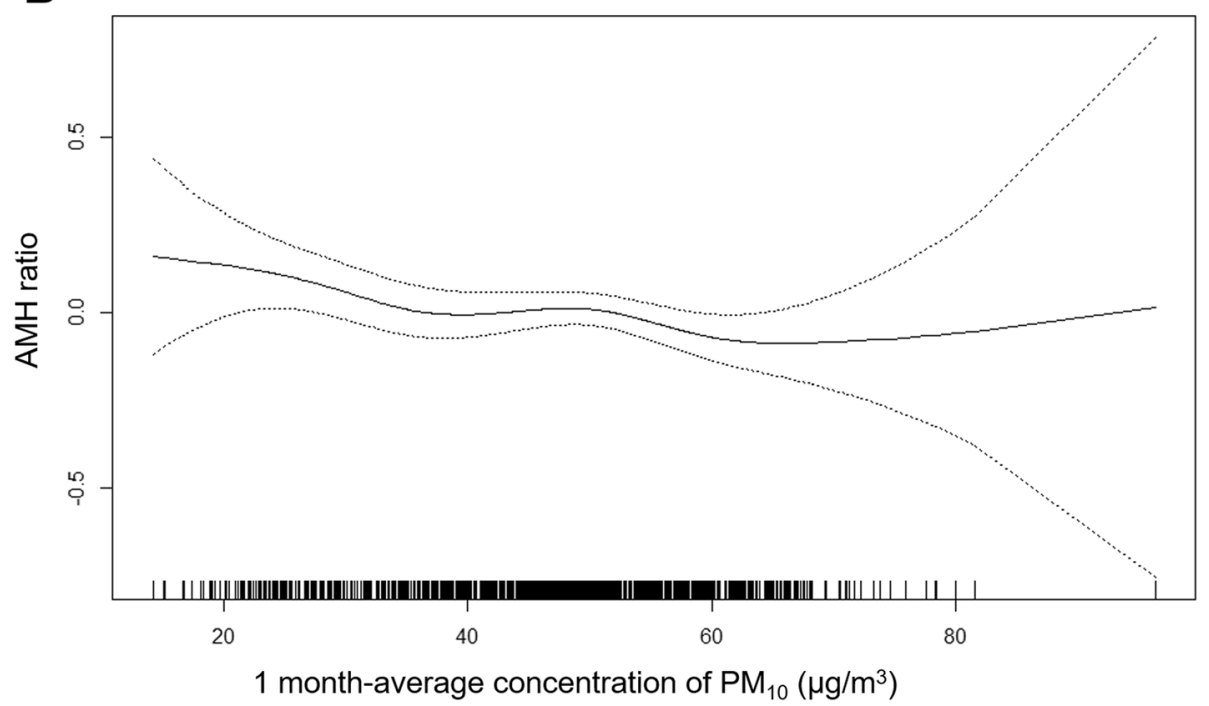

Fig. 1 Association between ovarian reserve and air pollutant concentrations. a A 1-month average $\mathrm{PM}_{10}$ and the AMH ratio in total population and $\mathbf{b}$ a 1-month average $\mathrm{PM}_{2.5}$ and the AMH ratio in Seoul residents. Generalized additive models with non-parametric smoothing splines were used. Interrupted lines indicate $95 \%$ confidence intervals of estimates.

more vulnerable population [46]. We believe the infertile patients will more clearly show the association between ovarian reserve and air pollution than general population. Second, our estimations of exposure to ambient air pollution were based on measurements from the nearest monitoring stations, and this may not constitute the actual levels of exposure. More refined measurement would minimize such a potential measurement bias. Third, we did not take account for other ovarian reserve indicators including antral follicle count, follicle-stimulating hormone, and number of oocytes retrieved in in vitro fertilization cycles. Because of high missing rate and low precision for these indicators, we used AMH levels as a sole indicator for ovarian reserve in this study. Studies with other ovarian reserve indicators will add evidence for the association between air pollution and ovarian reserve. Lastly, there is a possibility of false discovery with multiple testing. Given this is one of the limited studies exploring the association between AMH and air pollution, we present all the estimates and their significance using nominal $P$ value $(=0.05)$ differing air pollutants and exposure periods to facilitate further researches.

\section{Conclusions}

Using data from a young, infertile women, our study demonstrated that short-term exposures to higher PM 
levels were associated with lower age-adjusted level of AMH in infertile patients, highlighting the potential adverse impact of air pollution on human fertility and providing further evidence for the same. Further studies involving general population in different geographic and demographic settings are warranted to confirm the findings of this study.

\section{Supplementary Information}

The online version contains supplementary material available at https://doi. org/10.1186/s12199-021-00942-4.

Additional file 1: Figure S1. Correlation between the six air pollutants in 206 monitoring sites, 2016-2018. Table S1. Clinical characteristics and average concentration of six air pollutants for four exposure periods, normal ovarian reserve versus low AMH groups. Table S2. Odds ratios $(95 \%$

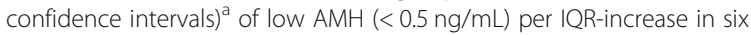
air pollutant concentrations in total population $(n=2,276)$ and Seoul residents $(n=1,122)$

\section{Abbreviations}

PM: Particulate matter ( $\mathrm{PM}_{10}$ and $\left.\mathrm{PM}_{2.5}\right) ; \mathrm{NO}_{2}$ : Nitrogen dioxide; $\mathrm{CO}$ : Carbon monoxide; $\mathrm{SO}_{2}$ : Sulfur dioxide; $\mathrm{O}_{3}$ : Ozone; $\mathrm{AMH}$ : Anti-Müllerian hormone; DOR: Diminished ovarian reserve

\section{Acknowledgements}

We thank Sun-Wha Shim and Shi-Ha Jung for their technical support.

\section{Authors' contributions}

SA Choe and $\mathrm{H}$ Kim conducted primary statistical analysis and wrote the draft. OJ Kim and SY Kim reviewed and revised the draft. S Kim and C Im conducted geospatial data production. YS Kim and Tae Ki Yoon supervised the process of study and provided the study data. The authors read and approved the final manuscript.

\section{Funding}

This research was supported by the National Research Foundation of Korea grant (NRF-2016R1D1A1B03933410 and 2018R1D1A1B07048821), which is funded by the Korean Government. This funding source had no role in study design, in the collection, analysis and interpretation of data, in the writing of the report, and in the decision to submit the article for publication. The contents of this report are solely the responsibility of the authors and do not necessarily represent the official views of the sponsoring organizations.

\section{Availability of data and materials}

The data are not publicly available due to the nature of information that could compromise the privacy of research participants.

\section{Ethics approval and consent to participate}

The study design was approved by the institutional review board of Gangnam CHA hospital ( $\mathrm{GCl}-18-48)$. As a research involving the retrospective review, this study qualified a waiver of informed consent.

\section{Consent for publication}

Not applicable.

\section{Competing interests}

The authors declare that they have no competing interests.

\section{Author details}

'Department of Obstetrics and Gynecology, CHA Fertility Center Seoul Station, CHA University School of Medicine, Seoul 04637, Korea. ${ }^{2}$ Department of Preventive Medicine, Korea University College of Medicine, Seoul 02841, South Korea. ${ }^{3}$ Department of Epidemiology \& Health Informatics, Graduate School of Public Health, Korea University, 73 Goryeodae-ro, Seongbuk-gu, Seoul 02841, Korea. ${ }^{4}$ Department of Cancer Control and Population Health Graduate School of Cancer Science and Policy, National Cancer Center,
Goyang-si, Gyeonggi-do 10408, Korea. ${ }^{5}$ Department of Public Health Science, Graduate School of Public Health, Seoul National University, Seoul 08826, Korea. ${ }^{6}$ Department of Geography, Korea University, Seoul 02841, South Korea.

Received: 22 October 2020 Accepted: 31 January 2021

Published online: 11 February 2021

\section{References}

1. Practice Committee of the American Society for Reproductive Medicine. Testing and interpreting measures of ovarian reserve: a committee opinion. Fertil Steril. 2015;103(3):e9-e17.

2. ESHRE. Fertility and ageing. Hum Reprod Update. 2005;11(3):261-76.

3. Liu K, Case A. Advanced reproductive age and fertility. J Obstet Gynaecol Can. 2011;33(11):1165-75.

4. Amanvermez R, Tosun M. An update on ovarian aging and ovarian reserve tests. Int J Fertil Steril. 2016;9(4):411-5.

5. Revelli A, Biasoni V, Gennarelli G, Canosa S, Dalmasso P, Benedetto C. IVF results in patients with very low serum $\mathrm{AMH}$ are significantly affected by chronological age. J Assist Reprod Genet. 2016;33(5):603-9.

6. Devine K, Mumford SL, Wu M, DeCherney AH, Hill MJ, Propst A. Diminished ovarian reserve in the United States assisted reproductive technology population: diagnostic trends among 181,536 cycles from the Society for Assisted Reproductive Technology Clinic Outcomes Reporting System. Fertil Steril. 2015;104(3):612-619.e613.

7. Gleicher N, Weghofer A, Oktay K, Barad D. Do etiologies of premature ovarian aging (POA) mimic those of premature ovarian failure (POF)? Human Reprod (Oxford, England). 2009;24(10):2395-400.

8. Bertone-Johnson ER, Manson JE, Purdue-Smithe AC, Steiner AZ, Eliassen AH, Hankinson SE, et al. Anti-Müllerian hormone levels and incidence of early natural menopause in a prospective study. Hum Reprod (Oxford, England). 2018;33(6):1175-82.

9. Santoro N, Randolph JF Jr. Reproductive hormones and the menopause transition. Obstet Gynecol Clin N Am. 2011;38(3):455-66.

10. Plante BJ, Cooper GS, Baird DD, Steiner AZ. The impact of smoking on antimüllerian hormone levels in women aged 38 to 50 years. Menopause (New York NY). 2010;17(3):571-6.

11. White AJ, Sandler DP, D'Aloisio AA, Stanczyk F, Whitworth KW, Baird DD, et al. Antimüllerian hormone in relation to tobacco and marijuana use and sources of indoor heating/cooking. Fertil Steril. 2016;106(3):723-30.

12. Dafopoulos A, Dafopoulos K, Georgoulias P, Galazios G, Limberis V, Tsikouras $P$, et al. Smoking and $\mathrm{AMH}$ levels in women with normal reproductive history. Arch Gynecol Obstet. 2010;282(2):215-9.

13. Hawkins Bressler L, Bernardi LA, De Chavez PJD, Baird DD, Carnethon MR, Marsh EE. Alcohol, cigarette smoking, and ovarian reserve in reproductiveage African-American women. Am J Obstet Gynecol. 2016;215(6):758.e7519.

14. Jurewicz J, Radwan M, Wielgomas B, Karwacka A, Klimowska A, Kałużny P, et al. Parameters of ovarian reserve in relation to urinary concentrations of parabens. Environ Health. 2020;19(1):26.

15. Abareshi F, Sharifi Z, Hekmatshoar R, Fallahi M, Lari Najafi M, Ahmadi Asour A, et al. Association of exposure to air pollution and green space with ovarian reserve hormones levels. Environ Res. 2020;184:109342.

16. Santi D, Marca AL, Michelangeli M, Casonati A, Grassi R, Baraldi E, et al. Ovarian reserve and exposure to environmental pollutants (ORExPo study). Endocr Abstr. 2019:63:P311.

17. Gaskins AJ, Mínguez-Alarcón L, Fong KC, Abdelmessih S, Coull BA, Chavarro $\mathrm{JE}$, et al. Exposure to fine particulate matter and ovarian reserve among women from a fertility clinic. Epidemiology. 2019;30(4):486-91.

18. Hall ES, Connolly N, Jones DE, DeFranco EA. Integrating public data sets for analysis of maternal airborne environmental exposures and stillbirth. AMIA Annu Symp Proc. 2014;2014:599-605

19. Piersanti A, Vitali L, Righini G, Cremona G, Ciancarella L. Spatial representativeness of air quality monitoring stations: a grid model based approach. Atmospheric Pollution Res. 2015:6(6):953-60.

20. Min K-D, Yi S-J, Kim H-C, Leem J-H, Kwon H-J, Hong S, et al. Association between exposure to traffic-related air pollution and pediatric allergic diseases based on modeled air pollution concentrations and traffic measures in Seoul, Korea: a comparative analysis. Environ Health. 2020;19(1):6-6. 
21. WHO. Health effects of particulate matter: policy implications for countries in eastern Europe, Caucasus and Central Asia. Copenhagen: WHO Regional Office for Europe; 2013.

22. Kim SY, O'Neill MS, Lee JT, Cho Y, Kim J, Kim H. Air pollution, socioeconomic position, and emergency hospital visits for asthma in Seoul, Korea. Int Arch Occup Environ Health. 2007:80(8):701-10.

23. Decanter C, Morschhauser F, Pigny P, Lefebvre C, Gallo C, Dewailly D. AntiMüllerian hormone follow-up in young women treated by chemotherapy for lymphoma: preliminary results. Reprod BioMed Online. 2010;20(2):280-5.

24. Wenners A, Grambach J, Koss J, Maass N, Jonat W, Schmutzler A, et al. Reduced ovarian reserve in young early breast cancer patients: preliminary data from a prospective cohort trial. BMC Cancer. 2017;17(1):632.

25. Conforti A, Mascia M, Cioffi G, De Angelis C, Coppola G, De Rosa P, et al. Air pollution and female fertility: a systematic review of literature. Reprod Biol Endocrinol. 2018;16(1):117.

26. Morin SJ, Patounakis G, Juneau CR, Neal SA, Scott RT Jr, Seli E. Diminished ovarian reserve and poor response to stimulation in patients \& It; 38 years old: a quantitative but not qualitative reduction in performance. Hum Reprod. 2018;33(8):1489-98

27. de Kat AC, Verschuren WMM, Eijkemans MJC, van der Schouw YT, Broekmans FJM. The association of low ovarian reserve with cardiovascular disease risk: a cross-sectional population-based study. Hum Reprod. 2016; 31(8):1866-74.

28. Lambrinoudaki I, Stergiotis S, Chatzivasileiou P, Augoulea A, Anagnostis P, Armeni $\mathrm{E}$, et al. Anti-Müllerian hormone concentrations are inversely associated with subclinical atherosclerosis in premenopausal women. Angiology. 2020;71(6):552-8.

29. Hur YJ, Yu EJ, Choe SA, Paek J, Kim YS. Peripheral blood natural killer cell proportion and ovarian function in women with recurrent implantation failure. Gynecol Endocrinol. 2020:1-4.

30. Lee JE, Park DS, Kim M-L, Yoon BS, Song T, Kim MK, et al. Age-related distribution of anti-mullerian hormone levels in 2,879 Korean women with regular menstruation. Korean. J Obstet Gynecol. 2012;55(12):920-8.

31. Lee JY, Jee BC, Lee JR, Kim CH, Park T, Yeon BR, et al. Age-related distributions of anti-Müllerian hormone level and anti-Müllerian hormone models. Acta Obstet Gynecol Scand. 2012;91(8):970-5.

32. Ferraretti AP, La Marca A, Fauser BC, Tarlatzis B, Nargund G, Gianaroli L. ESHRE consensus on the definition of 'poor response' to ovarian stimulation for in vitro fertilization: the Bologna criteria. Hum Reprod (Oxford, England). 2011;26(7):1616-24.

33. Abdalla $H$, Thum MY. An elevated basal FSH reflects a quantitative rathe than qualitative decline of the ovarian reserve. Hum Reprod. 2004;19(4):8938.

34. Gnoth C, Schuring AN, Friol K, Tigges J, Mallmann P, Godehardt E. Relevance of anti-Mullerian hormone measurement in a routine IVF program. Hum Reprod. 2008;23(6):1359-65.

35. WHO. Appropriate body-mass index for Asian populations and its implications for policy and intervention strategies. Lancet (London, England). 2004;363(9403):157-63.

36. Hg R, Heo J, Kim S-Y. Source apportionment of PM10 and PM2.5 air pollution, and possible impacts of study characteristics in South Korea. Environ Pollut. 2018;240:963-72.

37. Dockery DW, Pope CA, Xu X, Spengler JD, Ware JH, Fay ME, et al. An association between air pollution and mortality in six U. S cities. New England J Med. 1993;329(24):1753-9.

38. Brook RD, Franklin B, Cascio W, Hong Y, Howard G, Lipsett M, et al. Air pollution and cardiovascular disease. Circulation. 2004;109(21):2655-71.

39. Hime NJ, Marks GB, Cowie CT. A comparison of the health effects of ambient particulate matter air pollution from five emission sources. Int J Environ Res Public Health. 2018;15(6):1206.

40. Dechanet C, Anahory T, Mathieu Daude JC, Quantin X, Reyftmann L, Hamamah $\mathrm{S}$, et al. Effects of cigarette smoking on reproduction. Hum Reprod Update. 2010;17(1):76-95.

41. Ogliari KS, Lichtenfels AJ, de Marchi MR, Ferreira AT, Dolhnikoff M, Saldiva $\mathrm{PH}$. Intrauterine exposure to diesel exhaust diminishes adult ovarian reserve. Fertil Steril. 2013;99(6):1681-8.

42. Carré J, Gatimel N, Moreau J, Parinaud J, Léandri R. Does air pollution play a role in infertility?: a systematic review. Environ Health. 2017:16(1):82.

43. Veras MM, Damaceno-Rodrigues NR, Guimarães Silva RM, Scoriza JN, Saldiva $\mathrm{PH}$, Caldini EG, et al. Chronic exposure to fine particulate matter emitted by traffic affects reproductive and fetal outcomes in mice. Environ Res. 2009; 109(5):536-43.

44. Paszkowski T, Clarke RN, Hornstein MD. Smoking induces oxidative stress inside the Graafian follicle. Human Reprod (Oxford, England). 2002;17(4): 921-5.

45. Kelly FJ. Oxidative stress: its role in air pollution and adverse health effects. Occup Environ Med. 2003;60(8):612-6.

46. O'Neill MS, Breton CV, Devlin RB, Utell MJ. Air pollution and health: emerging information on susceptible populations. Air Qual Atmos Health. 2012;5(2):189-201.

\section{Publisher's Note}

Springer Nature remains neutral with regard to jurisdictional claims in published maps and institutional affiliations.
Ready to submit your research? Choose BMC and benefit from:

- fast, convenient online submission

- thorough peer review by experienced researchers in your field

- rapid publication on acceptance

- support for research data, including large and complex data types

- gold Open Access which fosters wider collaboration and increased citations

- maximum visibility for your research: over $100 \mathrm{M}$ website views per year

At BMC, research is always in progress.

Learn more biomedcentral.com/submissions 